\title{
Analysis of Modern Design Approach for Anti-Air Radar Screen
}

\author{
Jungwan Hong1, Suhwan Kim², Yongjin (James) Kwon ${ }^{*}$ \\ ${ }^{1}$ Department of Industrial Engineering, Ajou University, Suwon, South Korea \\ ${ }^{2} 1^{\text {st }}$ Division, $3^{\text {rd }}$ Department, Agency of Defense Development, Daejeon, South Korea \\ Email: *yk73@ajou.ac.kr
}

Received October 2015

\begin{abstract}
This study is a preparation phase for visualization of utilized information using ergonomic user interface and standardization of elements for anti-air radar screen. Therefore, we investigated the instances of anti-air radar screen for air defense weapon system for defense advanced country. Based on the collected data, we compared and analyzed the air defense weapon system radar screen design. In addition, we carry out a research for layout, configuration, standardization and design of the radar screen's elements. Ultimately, it is essential to share a variety of battle field conditions such as enemy threat, enemy/friendly information, terrain information that can be effectively recognized. In this paper, we conduct case study for ergonomically development of automated/standardized radar screen. It is expected that this research improves the situational awareness and reduces the user's task load.
\end{abstract}

\section{Keywords}

Anti-Air Radar Screen, Air Defense Weapon System, Human Interface, Ergronomics, Situational Awareness, Task Load

\section{Introduction}

It will be expected to lead to major changes of mission operation environment for air defense mission in the future shown as Table 1. According to dramatically improvement of missile target detection range with the development of radar detection technology and missile propellants, ballistic missile's flight speed and accuracy are also improved. Thus, it is necessary to quickly and effectively exhibit the enemy missiles that fly at rapid speed because ballistic missile will fly at Mach 3 to 10 in the future. Future integrated battlefield environment is required exhibition of various elements such as atmosphere, climate, terrain, enemy/friendly information factor [1]. Therefore, the study of the radar screen configuration suitable for mission operation environment condition is required. Table 2 shows direction of design for anti-air radar screen. As a result, effective handle is possible, grasp the trajectory of ballistic missile three-dimensionally [2]. Applying a touch-screen with a zoom-in function that can be observed a particular area of the wide range of attacks and it must be able to obtain detailed informa-

*Corresponding author. 
Table 1. Major changes of mission operation environment.

\begin{tabular}{|c|c|}
\hline Changed Situation & Requirements \\
\hline $\begin{array}{l}\text { Increase in detection range } \\
\text { and missile propellant range }\end{array}$ & $\begin{array}{l}\text { - } \quad \text { Development of radar detection and missile propulsion technology } \\
\text { - } \quad \text { Missile range, flying speed, accuracy are improved } \\
\text { - Expansion of scope for battle field }\end{array}$ \\
\hline $\begin{array}{l}\text { Short time of the battle } \\
\text { by the fast flight } \\
\text { speed of } \\
\text { ballistic missile }\end{array}$ & $\begin{array}{l}\text { - The speed of the ballistic missile is faster than normal aircraft speed } \\
\text { - } \quad \text { The high-speed combat will be occurred } \\
\text { - Quick and liquidity of certain capability will be required }\end{array}$ \\
\hline $\begin{array}{l}\text { Increased probability to engage } \\
\text { with an number of target }\end{array}$ & $\begin{array}{l}\text { - Clear situation awareness of commanders is required } \\
\text { - Fast and precise command decision is required }\end{array}$ \\
\hline
\end{tabular}

Table 2. Direction of design for radar screen.

\begin{tabular}{|c|c|}
\hline $\begin{array}{l}\text { Direction of Design } \\
\text { in Changed Situation }\end{array}$ & Description \\
\hline $\begin{array}{l}\text { Zoom-in/out function } \\
\text { through the touch-screen }\end{array}$ & $\begin{array}{l}\text { - Ability to see wide range of attacks quickly using zoom-function } \\
\text { - Display detailed information that does not degrade the overall situational awareness when zooming }\end{array}$ \\
\hline $\begin{array}{l}\text { Switch function/ } \\
\text { Simultaneous } \\
\text { display function } \\
\text { 2D, 2.5D, 3D } \\
\text { (dimension) }\end{array}$ & $\begin{array}{l}\text { - Determine the trajectory of the ballistic missile in 3D as well as 2D } \\
\text { - Determine efficiencies for various radar screen's component layout }\end{array}$ \\
\hline $\begin{array}{l}\text { Rapid and accurate } \\
\text { situational awareness }\end{array}$ & $\begin{array}{l}\text { - Utilization of agronomical symbol for component of radar screen } \\
\text { - Representation of friendly/enemy/missile/asset with high readability } \\
\text { - Quick and accurate threat analysis through rapid situational awareness }\end{array}$ \\
\hline $\begin{array}{l}\text { Expression of intensive } \\
\text { information through } \\
\text { the large screen }\end{array}$ & $\begin{array}{l}\text { - Apply high-resolution LCD touch-screen } \\
\text { - } \text { Minimize the time to load information } \\
\text { Prevention of essential missing information }\end{array}$ \\
\hline
\end{tabular}

tion to that area. In addition, represent assets of enemy and friendly using the symbol based on ergonomics of the radar screen's elements and then it should be designed to allow rapid situation awareness. Through a large screen like a 30-inch LCD touch-screen allows broad sense representations of information, further it must be minimize the time to import battlefield information [3].

\section{Case Study}

\section{Air Defense Weapon System Radar Screen}

- Case study for 12 kinds of radar screen for air defense weapon systems.

- Attack range/altitude, mission, intercept altitude, operating country etc.

- Threat information, friendship information, tactical situation information, the operation of the tactical map equipment, the type of air defense weapon system components etc.

- Air defense weapon system radar screen's configuration and layout.

- Major Air defense weapon systems are shown as Table 3.

- Tables 4-7 show results of analysis for radar screen.

\section{Results}

This study analyzes the common characteristics and flow of air defense weapon system's radar screen. Also features of each radar screen elements are analyzed as a graph. 


\subsection{Radar Screen Shape/Location/Background/Color}
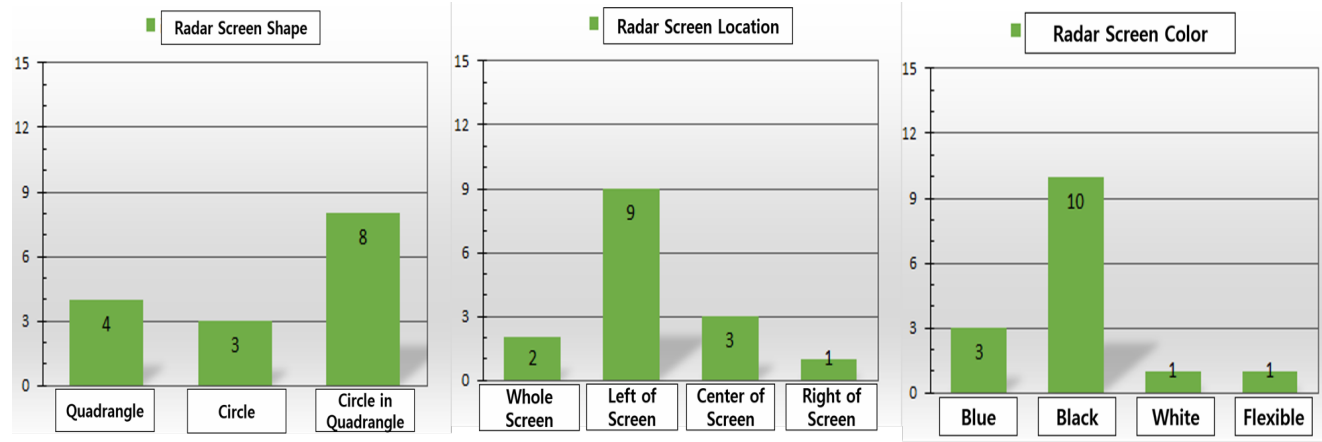

Figure 1. Analysis results of shape, location, color for radar screen.

\subsection{Radar Screen Text Information and Tactical Map}
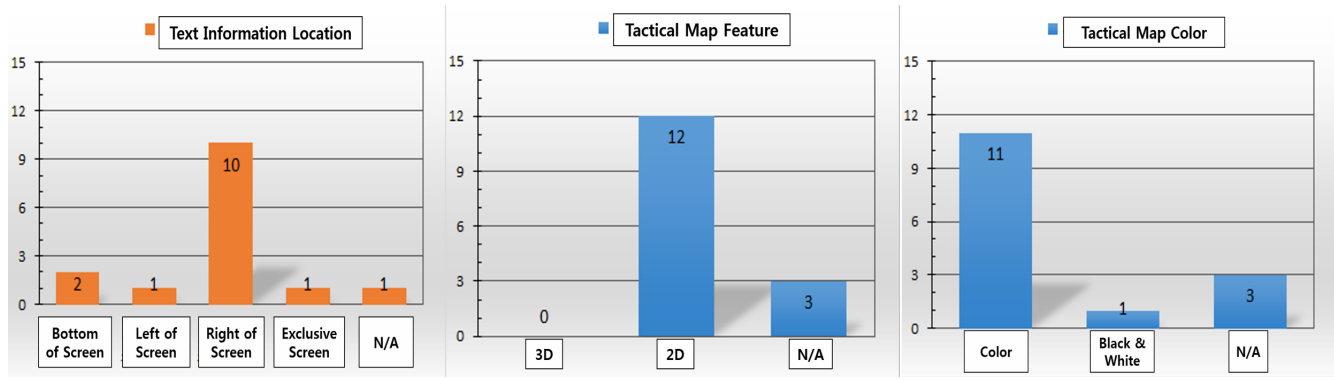

Figure 2. Analysis results of text information and tactical map for radar screen.

Table 3. Major air defense weapon systems.

\begin{tabular}{ccc}
\hline Air Defense Weapon System & Nation & Attack Range/Altitude \\
\hline THAAD & USA (Lockheed) & $200 / 100$ \\
Patriot (PAC-1, 2, 3) & USA (Raytheon) & $160 / 24$ \\
Arrow-2, 3 & USA + Israel & $100 / 50$ \\
MEADS & USA + Germany + Italy & 30 (Detection Range) \\
PANTSIR-S1 & Russia & $32 / 15$ \\
Tor M-1 & Russia & $25 / 12$ \\
OSA & Russia & $15 / 12$ \\
S-300/400 & Russia & $25 / 70$ \\
Polyana d4m1 & Russia & 2400 (Detection Range) \\
SAMP/T & France & $40 / 15$ \\
MCDS & Italy & $30 / 15$ \\
\hline
\end{tabular}

\section{Conclusion}

Radar screen which form is circular shape onto a quadrangle screen taking the largest proportion. Position of radar screen mostly is displayed on the left side of its screen. Its background's color is usually dark color such as black, blue, indigo. Text information of radar screen is normally on its right side. Recent radar screen system has evolved into free-form with adapting its components to user's convenience. Recent trend of radar screen is including Tactical map into its components. Previous trend is using 2D color Tactical map. In the future warfare, radar screen will need 2.5D, 3D Tactical map. Most of radar screens have 4 monitor up down left right side. The number of user will be 2 or 3 , and their assignments are detecting radar screen, management of arm and total control. Table 8 shows results. 
Table 4. Radar screen layout analysis (1).

\begin{tabular}{|c|c|c|c|}
\hline Name & THAAD & Patriot PAC-1, 2 (old type) & Patriot PAC-3 (the newest) \\
\hline \multicolumn{4}{|l|}{$\begin{array}{l}\text { Radar Screen } \\
\text { Layout }\end{array}$} \\
\hline Shape & Quadrangle & Circle & Circle in Quadrangle \\
\hline Location & Whole screen & Center of screen & Center of screen \\
\hline $\begin{array}{c}\text { Color } \\
\text { (Background/Symbol) }\end{array}$ & Blue/White & Black/Green & Black/Various color \\
\hline \multirow{3}{*}{$\begin{array}{l}\text { Shape } \\
\text { Location } \\
\text { Color }\end{array}$} & N/A & Text type & Text type \\
\hline & N/A & Bottom of screen & Bottom of screen \\
\hline & White & Green & White \\
\hline $\begin{array}{c}\text { Tactical Map } \\
\text { (Available/Resolution/Color) }\end{array}$ & Available/2D/Color & N/A & Available/2D/Color \\
\hline Number of Operator & 2 & 3 & 3 \\
\hline Role & $\begin{array}{l}\text { Radar detection, } \\
\text { Targeting and } \\
\text { Fire operation }\end{array}$ & $\begin{array}{c}\text { Radar detection, } \\
\text { Targeting and } \\
\text { Fire operation, } \\
\text { Whole situational awareness }\end{array}$ & $\begin{array}{c}\text { Radar detection, } \\
\text { Targeting and } \\
\text { Fire operation, } \\
\text { Whole situational awareness }\end{array}$ \\
\hline Total Display & 2 & 2 & 4 \\
\hline
\end{tabular}

Table 5. Radar screen layout analysis (2).

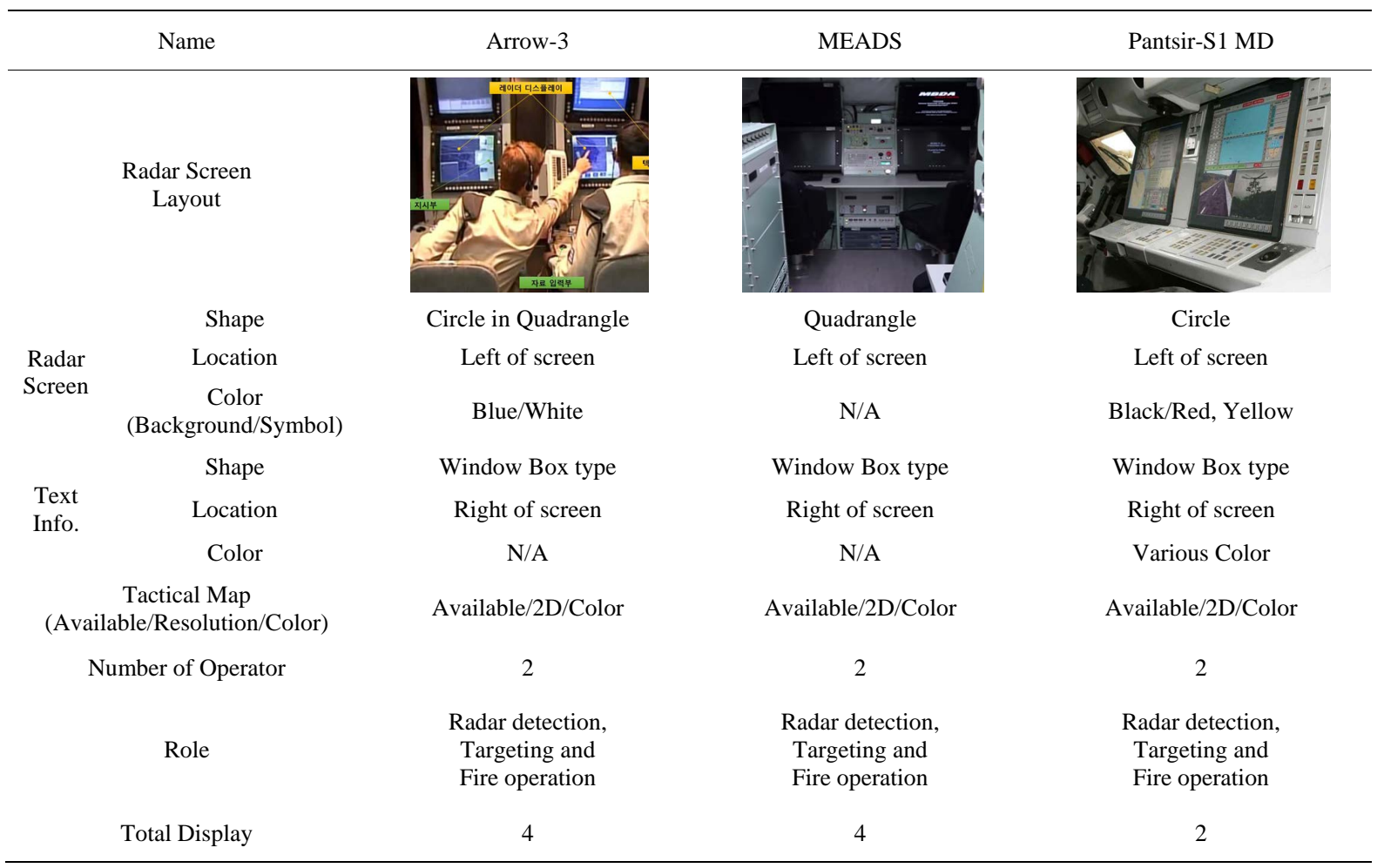


Table 6. Radar screen layout analysis (3).

Name
Radar Screen
Layout

Table 7. Radar screen layout analysis (4).

\begin{tabular}{|c|c|c|c|}
\hline Name & S-300 & Polyana D4M1 & $\mathrm{SAMP} / \mathrm{T}$ \\
\hline \multicolumn{4}{|l|}{$\begin{array}{l}\text { Radar Screen } \\
\text { Layout }\end{array}$} \\
\hline Shape & Circle in Quadrangle & Quadrangle & Circle in Quadrangle \\
\hline Location & Left of screen & Left of screen & Left of screen \\
\hline $\begin{array}{c}\text { Color } \\
\text { (Background/Symbol) }\end{array}$ & Black/Various Color & White/Black, Red, Blue & Black/Various Color \\
\hline Shape & Window Box type & Window Box type & Window Box type \\
\hline $\begin{array}{l}\text { Text } \\
\text { Info. }\end{array}$ & $\begin{array}{l}\text { Right of screen } \\
\text { (Flexible layout) }\end{array}$ & Right of screen & Right of screen \\
\hline Color & Various Color & Black & Various Color \\
\hline $\begin{array}{c}\text { Tactical Map } \\
\text { (Available/Resolution/Color) }\end{array}$ & N/A & Available/2D/White \& Black & Available/2D/Color \\
\hline Number of Operator & 2 & 7 & 3 \\
\hline Role & $\begin{array}{c}\text { Radar detection, } \\
\text { Targeting and } \\
\text { Fire operation }\end{array}$ & $\begin{array}{c}\text { Radar detection, } \\
\text { Targeting and } \\
\text { Fire operation, } \\
\text { Whole situational awareness }\end{array}$ & $\begin{array}{c}\text { Radar detection, } \\
\text { Targeting and } \\
\text { Fire operation, } \\
\text { Whole situational awareness }\end{array}$ \\
\hline Total Display & 4 & 7 & 5 \\
\hline
\end{tabular}


Table 8. Radar screen layout analysis results.

\begin{tabular}{ccc}
\hline Division & Analysis Results & Case of Air Defense Weapon System \\
\hline Radar Screen Feature & Circle Radar Screen & Patriot series, S-300, Tor M-1, Arrow-3 \\
Radar Screen Location & Left of Display & Arrow-3, Pantsir-S1 etc. \\
Radar Screen Color & Black & SAMP/T, MCDS, OSA etc. \\
Text Information Location & Right side of Radar Screen & Pantsir-S1, Arrow-3 etc. \\
Tactical Map Feature & 2D Tactical Map & THHAD, the Newest Patriot etc. \\
Tactical Map Color & Color Type & THHAD, the Newest Patriot etc.
\end{tabular}

\section{Acknowledgements}

This work was supported by the Agency for Defense Development (ADD) under the Contract No. UD140066CD. The authors wish to express sincere gratitude for the financial support.

\section{References}

[1] Olmos, O., Wickens, C.D. and Chudy, A. (2014) Tactical Displays for Combat Awareness: An Examination of Dimensionality and Frame of Reference Concepts and the Application of Cognitive Engineering. The International Journal of Aviation Psychology, 10, 247-271. http://dx.doi.org/10.1207/S15327108IJAP1003_03

[2] Brown, C., Fagan, P., Hepplewhite, A., Irving, B., Lane, D. and Squire, E. (2014) Real-Time Decision Support for the Anti-Air Warfare Commander. Proc. 6th Int. Command Control Res. Technol. Symp. (ICCRTS), 2001.

[3] Filippidis, A., Blandford, S., Foster, K. and Moran, G. (2006) Simulation Activities Using Gateway and Tactical Digital Information Links. Defence Science and Technology Organisation, 1-13. 